\title{
Justifications for Medical Quarantine in Jewish Ethics
}

\author{
Tsuriel Rashi ${ }^{1}$
}

Accepted: 28 August 2020 / Published online: 18 September 2020

○) Springer Science+Business Media, LLC, part of Springer Nature 2020

\begin{abstract}
The current Corona epidemic broke out at the end of 2019 and by early in the year 2020 was spreading all around the world from China to the USA. Among the moves in the fight against the proliferation of the illness, international borders were closed to prevent travel among countries. In the next stage in the fight, many countries imposed quarantines on carriers of the disease as well as on those around them and even on entire civilian populations. Herein, I offer the religious justifications in Judaism for preserving the public's health in general and particularly in the face of disease, especially during of the course of an epidemic. Similarly, I also deal with the religious requirements for preventing the spread of an illness, which come at the expense of fulfilling religious commandments (mitzvot) and suspending them with a view toward preserving life. My conclusion is that ever since the time of the Bible, Judaism has viewed the maintenance of health as having social, religious, and medical importance. Rabbis over the last centuries have justified separating and isolating the sick and extending that isolation to individuals who are in danger of succumbing to the illness. They have found religious justifications for issuing instructions to suspend religious observances in order to prevent the spread of a disease, as is the case in the epidemic that the world is now experiencing with the Corona virus.
\end{abstract}

Keywords Quarantine · Isolation · Judaism · Ethics

\section{Background}

The Corona virus (COVID-19) global epidemic broke out at the end of 2019. The virus of the SARS-CoV-2 strain passed from infected animals to humans and to the present date has caused hundreds of thousands to be infected and dozens of thousand deaths. At first, most of the morbidity was seen in China. However, from the middle of February 2020 the virus started to spread rapidly and by the middle of March had reached 150 countries and caused a worldwide panic. At the beginning of

Tsuriel Rashi

Tsuriel.rashi@gmail.com

1 Ariel University, Ariel, Israel

记 Springer 
March 2020, the World Health Organization declared a pandemic. The responses of governing bodies and health systems around the world have included various restrictions, from imposing curfews to canceling flights, to closing down complete sectors of the economy, to calling for self-isolation (quarantine) in their homes for millions. ${ }^{1}$

Self-isolation at home has been recommended for both those diagnosed with COVID-19 and those who suspect that they may have been infected. The virus has reached the stage of community spread in large parts of the world, which means that it is proliferating within communities whose members have not necessarily travelled to areas with widespread transmission. Government health agencies recommend that individuals self-isolate if they develop a continuous cough or a high fever. The selfisolation period should last for at least 14 days but preferably longer. ${ }^{2}$ Some government health agencies have ordered individuals who have travelled to a country with widespread transmission or who have been in direct contact with someone diagnosed with COVID-19 to self-quarantine and practice social distancing for 14 days from the time of last possible exposure. ${ }^{3}$

The National Health Services have recommended that those self-quarantining at home stay $2 \mathrm{~m}$ (6.6 feet) away from others within the household. Individuals in selfquarantine have been instructed to avoid contact with the elderly and chronically ill. They should wash their hands regularly so that they do not spread the disease to others in the house or onto surfaces and objects that others will touch. They should only contact health services if the symptoms worsen significantly.

There are two key characteristics of every religion-conservatism and community. A religion has an array of clear, established rules; over time, it creates ceremonies and customs that let believers express their share in its maintenance. Moreover, it is not inclined to change them and introduce innovations that might cause deviations from its path. At the same time, religion requires a community, or it will die, but nonetheless there is an element of isolation in all religions-monasticism, asceticism, seclusion, self-mortification-but at least in Abrahamic religions, it is generally limited and contained within clear and well-formulated frameworks of times and places. Mainstream religious activities are public and visible. The Corona virus has dealt a serious blow to both conservatism and the community. Herein, I examine in particular the religious justifications for civilian quarantine in the light of Jewish philosophy and ethics, justifications that are tantamount to the suspension of many accepted religious norms. This article is a historical and rational review of Jewish responses to epidemics and the legal rulings handed down in light of them.

\footnotetext{
1 "Coronavirus: Shanghai neighbor Zhejiang imposes draconian quarantine." South China Morning Post. 6 February 2020. Archived from the original on 6 February 2020. Retrieved 8 February 2020.

2 "Overview-Coronavirus (COVID-19)". NHS.uk. UK National Health Service. Retrieved 15 March 2020 from: www.nhs.uk/conditions/coronavirus-covid-19/.

3 "COVID-19 Travel Precautions." CDC.gov. US Centers for Disease Control and Prevention. 11 February 2020. Retrieved 6 March 2020 from: https://www.cdc.gov/coronavirus/2019-ncov/travelers/after -travel-precautions.html.
} 


\section{Biblical Injunctions Regarding the Concern for the Medical Well-Being of One's Fellow Man as a Duty to God}

As early as in the Bible, there is evidence of epidemics that claimed many victims. For example, one of the ten plagues that the Egyptians suffered was murrain, which affected their animals (Exodus 9:1-8). In the Bible, a plague is seen as a heaven-sent punishment for unacceptable acts: from the Ten Plagues in Egypt through the warnings in Leviticus and Deuteronomy; to the plagues caused by improper handling of the Ark of the Covenant among the Philistines (Samuel 1:5) and the people of Beit Shemesh (Samuel 1:6); and later among the other inhabitants of the Land of Israel from the city of Dan in the north to Beersheba in the south (Samuel 2:14). Thus, clearly, Jewish tradition also sees the obligation to deal with the plague from two perspectives: the religious aspect, which calls for self-correction, fasting, and prayer, and the medical and civil challenges.

The emphasis on a plague that causes widespread death and the understanding that this is an epidemic, and not "just" a disease is also found in the Mishnah, the first major written collection of the Jewish oral traditions known as the Oral Torah. For example, in the Mishnah Ta'anit, there are natural phenomena that call for a fast, such as murrain:

And so too a city which has a plague or [its buildings] collapse that city fasts and they sound a blast, but those [in the places] around it fast but do not sound the alarm. Rabbi Akiva says: they sound the alarm but do not fast. What constitutes a plague? If in a city that can supply five hundred footsoldiers and three deaths occurred on three consecutive days, behold this constitutes a plague, less than this is not a plague. (Mishna, Ta'anit, 3:4).

In the Talmud, there is a more complex development of this "test," and later sources have also added metrics that could influence the proclamation of a fast, such as "convoys moving from place to place" which might spread the disease. Thus, Maimonides (Moses ben Maimon [1138-1204]), one of the most important legal arbiters in Jewish history, summed it up:

These are the troubles of the community about which we fast and sound [trumpets]... about a plague.... About a plague-how is this? What is a plague? A city that has five hundred footmen and three of them died in three days-one after [the other] - this is surely a plague. If they were eliminated in one day or in four days, it is not a plague. If there were a thousand and six of them were eliminated in three days-one after [the other-this is] a plague. If they were eliminated in one day or in four days, it is not a plague. And so forth, according to this calculation. And women, minors, and old men that have stopped from working are not in the count of the people of the province regarding this matter. [If] there was a plague in the Land of Israel, the rest of the exiles of Israel should fast about them. If there was a plague in a province and there are caravans coming from it to another province-both of them should fast, even though they are far from one [another]. (Laws of Fasts, 2: 1, 5-6). 
Prayer and fasting in light of the plague that has harmed the communities themselves or other communities reflect the understanding that there is a mutual responsibility to care for others wherever they are.

However, apart from that, epidemics are not only subject to theological considerations but involve a series of medical and social imperatives that are strengthened by religious norms. Maimonides, who was also a philosopher and physician, was not satisfied with just the religious commandment to pray and fast during a plague. He insisted that there is a halachic obligation to not only to treat disease but also to prevent it from spreading and that doing so requires medical and social concerns:

Seeing that the maintenance of the body in a healthy and sound condition is a God-chosen way, for, lo, it is impossible that one should understand or know aught of the divine knowledge concerning the Creator when he is sick, it is necessary for man to distance himself from things which destroy the body and accustom himself in things which are healthful and life-imparting.

\section{(Hilchot De'ot [Laws of Human Dispositions], Chap. 4, Halacha 1):}

That is to say, every individual must look after his/her own health so as not to become ill. Thus, as a doctor, he noted that people should not eat unhealthy foods and should protect themselves from catching a cold and from all other things that can harm the body.

Maimonides basically argued that one has to avoid getting sick because an unhealthy person cannot worship God in a suitable fashion, nor can such a person study properly. Functioning simultaneously as a physician and religious leader, he argued that one has a duty to protect oneself from activities that damage one's health because health is both a good in and of itself and it is difficult for an unhealthy person to fulfill religious duties. He found his proof text for both of these arguments within the following biblical injunctions, "Only be careful, and watch yourselves closely" (Deuteronomy 4:9) and "Therefore watch yourselves very carefully" (Deuteronomy 4:15). Further, in the Babylonian Talmud (Treatise Ta' anit 22B), based on Genesis 2:7, we read, "the man became a living being"- the soul I gave you-keep it alive. Maimonides also noted, "If any obstacle involves a danger to life, it is a positive command to remove it and to be aware of it, and to take particular care to be very careful, as it says: "Only be careful, and watch yourselves closely"” (Hilchot Murderer and the Preservation of Life, Chaps 11 and 12). Clearly, the import of these words is that the duty of maintaining health is a religious obligation of a man toward his God.

\section{The Duty to Heal as Part of One's Responsibility to Others}

Maimonides also expanded the prohibition of the duty to heal into a general guideline: "The sages have prohibited many things because they are dangerous to life. If anyone disregards them and says: 'What claim have others on me if I risk my own life?' or 'I do not mind this,' he should be lashed for disobedience" (Hilchot 
Murderer and the Preservation if Life, Chap. 11, Halacha 5). That is to say, according to Maimonides, every instruction issued concerning taking care to protect the well-being of the body and its health is an indication that it is forbidden for an individual to put himself and others in danger or to treat the instructions he has been given with contempt. If a person does not do so, he should be punished by flogging at the discretion of the rabbinical court because such an act is part of one's religious duty toward others.

Maimonides' injunction draws on biblical verses that declare that a person must not limit himself to worrying about his own health but should also be concerned about the health of his fellow. For example, as in Leviticus 19:16, "Do not do anything that endangers your neighbor's life," and Leviticus 19:18, "Love your neighbor as yourself." These biblical injunctions are rules and specific instructions as to how to act in particular situations. Thus, in Hilchot Mourning, Chap. 14, Halacha 1, he wrote: "You shall love your neighbor as yourself" (Leviticus 19:18); that is, whatever you would have others do to you, do to your brothers. In other words, love for another is expressed by a series of deeds that in fact every person would wish would be done for him, and he is required to do them himself.

Some halachic arbiters understood that the biblical prohibitions also had medical and social significance. For example, the ruling of Rabbi Judah ben Samuel of Regensburg (1150-1217), also known as Rabbi Yehuda HaHasid, Rabbi Yehuda HeHasid, or 'Judah the Pious' in Hebrew, who was a leader of the Chassidei Ashkenaz, a movement of Jewish mysticism in Germany, is especially relevant. ${ }^{4}$ Among other adjudicators, Rabbi Yehuda HeHasid wrote that the biblical commands to love one's neighbor and not to place stumbling blocks before him are valid when a person is sick and might infect others:

Do not... put a stumbling block in front of the blind" (Leviticus 19:14), that a person with a contagious skin disease should not bathe with another Jew unless he informed him first, as it is written (op. cit. 18) "Love your neighbor as yourself" (op. cit. 19) and "Do not do anything that endangers your neighbor's life (op. cit. 16) (Sefer Chasidim (Margoliot), Sect. 773).

That is to say, a sick person is obliged to warn those around him against the possibility that he might transmit the infection, an obligation that derives directly from biblical commandments. Moreover, Rabbi Yehuda HeHasid's words are completely in line with the halachic rulings of the Baalei Tosafot, the twelfth- to fifteenth-century French and German rabbis who wrote critical and explanatory glosses (questions, notes, interpretations, rulings, and sources) on the Talmud, collectively called Tosafot (additions). The Tosafot are important for the practical application of Jewish law because that law depends on how the Talmud is understood and interpreted.

In one of their commentaries on the Babylonian Talmud, the Tosafists wrote: "A person must make greater effort not to harm someone else than not to be harmed himself' (Treatise Bava Kama 23A). It is important to understand that this

\footnotetext{
${ }^{4}$ For further discussion, see: "Judah ben Samuel: German Jewish mystic," britannica.com. Retrieved October 10, 2019.
} 
interpretation from medieval times is based on an understanding formulated over the years among halachic arbiters about the obligation to preserve health in general, to guard personally against illness, and to be extremely careful during an epidemic.

\section{The Religious Duty to Maintain One's Own Health}

In Treatise Terumot Chap. 8, Halacha 3, the Jerusalem Talmud ruled that it was prohibited to put a coin in one's mouth. Rabbi Nissim Gerondi (1315-1376), one of the great Talmudic commentators, had a scientific, philosophical, and medical education. In his commentary on the Talmud (Babylonian Talmud Treatise Avoda Zara 10B), he explained that the Talmudic prohibition was rendered "because everyone touches them and they bear sickness and dirt sticks to them." In his Shulchan Aruch (Yoreh Deah Sect. 116 subsection 5), Rabbi Joseph Karo (1488-1575), one of the greatest of the halachic arbiters, ruled this as halacha, noting: "One must refrain from putting coins in one's mouth, lest they are covered with dried saliva of those afflicted with boils."

Further, Rabbi Moshe Isserles (1530-1572), an eminent Polish Ashkenazi rabbi, Talmudist, and adjudicator, expanded the halachic ruling, noting:

Similarly, he should be careful of all things that cause danger, because danger is stricter than transgressions, and one should be more careful with an uncertain danger than with an uncertain religious prohibition.... And all of these things are because of the danger, and a person who guards his soul will distance himself from them and it is prohibited to rely on a miracle in all of these matters.

That is to say, every person has a responsibility to identify a danger and to be much more concerned about the threat than about transgressing a religious prohibition. Moreover, a man must be concerned even in a situation in which he is not certain he himself will be harmed; further, it is forbidden to count on a miracle to justify endangering oneself.

In line with these religious injunctions, taking account of the increasing spread of the Corona virus, in March 2020 the Sephardi Chief Rabbi of Israel Rabbi Yitzhak Yosef decreed that people should stop kissing mezuzot, the hand-written scrolls with a few verses from Scripture in a cylinder attached to the doorpost of a Jewish home. Under Jewish law, there is a distinction between a custom and a binding law that all must follow, and kissing the mezuzah is a custom.

By the same token, the Ashkenazi Chief Rabbi of Israel Rabbi David Lau issued a ruling that people should stop kissing the mezuzah when they enter or depart Jewish homes:

In these days, where sadly we see the spread of a terrible disease, there is doubt that one should not kiss mezuzot or even touch them," Lau wrote. "It is enough for a person to reflect on the verses written in the scroll when he enters or departs from a place, and these thoughts will accompany him on his way. (Jerusalem Post 2020). 


\section{The Requirement to Take Extreme Care of One's Self During an Epidemic}

The Babylonian Talmud (Treatise Bava Kama 60B) rules that: "if there is plague in the town, go home, as it is written, 'And a person shall not leave his home until the morning' and in the Bible we read "Go, my people, enter your rooms and shut the doors behind you" (Isaiah 26:20) and "In the street the sword will make them childless; in their homes terror will reign" (Deuteronomy 32:25). The Talmud asks why it is necessary to base its statement on several biblical verses and explains that the obligation holds both at night and during the day and that it is an obligation that applies to both the individual and the community.

Shmuel Eidels (1555-1631), also known as Maharsha (a Hebrew acronym for "our teacher), a renowned rabbi famous for his commentary on the Talmud, entitled Chiddushei Halachot, explained that the meaning of the Talmudic ruling is that for the entire time that one has not left the town, one should stay in his home and not go out into the street. The Talmud (op. cit.) continues: "Plague in the town-do not go in the center of the road... Peace in the town, do not go along the sides of the road." Rabbi Shlomo Ben Shimon Duran (1400-1467), a rabbi and halachic arbiter in Algiers, explained that guideline in one of his Responsa (Sect. 195) allegorically, noting:

At a time of health a person must behave in a measured and reasonable manner in what he eats and drinks, how he dresses, in his sleep and when he wakes... when he moves about and when he rests and in his emotional moments. That is to say in his joy and sadness, in his anger and his satisfaction and in all the other things that are necessary for the body's well-being, an individual must be moderate-not too much and not too little, but during an epidemic he must take extra care and should not only forego excess and not consume too much, but also eat healthy foods in small quantities, rest more, and avoid physical contact with others. All this is at an extreme, but the middle road is insufficient, and that is the meaning of "do not go in the center of the road but along the side."

Rabbi Duran's interpretation deviates from the straightforward understanding of the Talmudic injunction, does not provide an answer as to how someone should go in the streets of his town, and expands the meaning into an innovative, wise statement of a moral lesson. Here, Rabbi Duran shows himself as a follower of Maimonides' Aristotelianism in that while the mean typically is the appropriate choice, when dealing with an extreme on one end, one has to go to the extreme on the other end. In effect, he is saying that owing to the greater danger during an epidemic, a person must face the fact that he is obliged to take greater care regarding his actions than in normal times. 


\section{How Jewish Ethics Deals with an Epidemic: A View of Duties to God and to the Other}

Rabbi Chaim Falaji (1787-1868), one of the leading rabbis in Izmir, Turkey, was a halachic arbiter, a commentator, and a kabbalist. In his book Nishmat Kol Chai (Part 2, Choshen Mishpat Sect. 49), he wrote that at the beginning of his career he was asked about a synagogue where a doctor who was treating the sick during an epidemic wanted to come to the synagogue. The other members of the community did not allow him to enter because they were afraid that contact with him would make them ill. Rabbi Palaji noted that he had supported the members of the congregation and had ruled that the doctor was not to be admitted.

This responsibility toward another during an epidemic was also explained by Rabbi Israel Lipschitz (1782-1862), one of the most important rabbis in Germany, the author of the commentary Tiferet Yisrael on the Mishnah. In the section dealing with Tiferet Yisrael-Boaz (Treatise Ketubot Chap. 7, Item 1), he wrote: "When Heaven forfend there is an infectious disease, and even if questionable whether it is infectious such as cholera and others, a man is forbidden to hire people to work for him or to bury any members of his family." That is to say, a person should not employ people for personal benefit when he might endanger them.

The most comprehensive and in-depth instructions penned by a rabbi in respect to actions during an epidemic were actually written 200 years ago when there was an outbreak of cholera in Poland, at which that time, Rabbi Akiva Eger served as a rabbi there. Originally from Posen, Germany, Rabbi Eger (1761-1837), who was an outstanding early nineteenth-century Talmudic scholar, an influential halachic decisor, and a foremost leader of European Jewry, instituted regulations that greatly helped prevent the spread of the disease, including directives to isolate areas of infection. In his rulings, he merged duty to God and to others. He appointed a committee that would be responsible for hygiene in public places and for raising awareness among the people. He ensured that the committee would fund cleaning services for the alms houses and distributed posters concerning the religious obligation to protect one's health by boiling drinking water and pursuing personal hygiene. On one occasion, he wrote: "I have already warned time after time that their behavior should be... as organized and adjudged by the doctors... and not to violate what they say" (Letters of Rabbi Akiva Eger 81, 83, Novellae of Rabbi Akiva Eger, Nedarim 39). In this spirit, he did not hesitate to suspend religious customs and laws for the duration of the epidemic.

As is well known, in Jewish law at least ten adult Jewish men from the age of thirteen (a minyan) have to come together to fulfill certain commandments, such as saying particular prayers in the three daily services. In order to keep crowds from gathering, which even then was perceived as a very serious danger for the spread of disease, Rabbi Eger ruled that prayers with a minyan should be waived when the space was narrow and people were likely to be crowded together. Even when there is enough space in the synagogue, he insisted that the congregation pray in small groups: 
Concerning prayer in the synagogue, in my opinion gathering together in a small space is not right, but people can pray in separate groups, each time in small numbers, about fifteen people and to recite selected psalms after the prayers morning and evening, and to mention his Majesty the King, his family and councilors and all the inhabitants of his country.

Further, he called on the people to be meticulous about following the instructions of the doctors and the government alongside the communal and moral directives he had stipulated and to involve the authorities in helping enforce the rules against those who violate them.

In that year, in the weeks leading up to the Days of Awe, the holiday period at the start of the Jewish year, in order to reduce the number of people gathering, Rabbi Eger declared that there would be a lottery to determine which members of the community would pray in the synagogue on each of the two days of Rosh Hashana (New Year) and which on Yom Kippur (the Day of Atonement). Similarly, he canceled the usual gathering for the collection of donations on Yom Kippur eve. ${ }^{5}$ He also significantly shortened the prayers themselves and set long breaks between the prayer sections. In coordination with the local authorities, policemen were brought into the synagogues to preserve order and to prevent crowding when people entered and left. He ordered the entire community to have a hot drink before the morning service despite the custom of not eating or drinking before the morning prayers.

It should be noted that Rabbi Eger did not limit himself to communal guidelines but related to personal obligations as well: to dress properly and to avoid harmful foods and alcohol. He gave instructions to air out rooms and insisted on household hygiene, which included cleaning and washing the house with water and vinegar: "Be clean, do not leave a mess and dirt in the house." He adopted in full the local medical guidelines of his times, and elsewhere he wrote: "Someone who transgresses the words of the doctors in this matter sins greatly before G-d, and his sin is too great to bear." He also issued instructions regarding the spiritual sphere, creating prayers, decreeing the recitation of special psalms, and stipulating the amount of charity to be collected from each person for redemption of his soul. His instructions were punctilious, stringent, and decisive. He also circulated a further directive, no less decisive, calling for optimism and insisted that people should try not to worry and to avoid feelings of sadness.

Obviously, some of Rabbi Eger's medical instructions are no longer relevant as mankind has advanced and technology and medical knowledge have progressed. For example, he spoke about eating mustard seeds and changing clothes more than twice a week. Today, we do not have to eat mustard seeds to handle diseases, and we generally change our clothes more than twice a week. Be that as it may, his regulations helped stopped the cholera epidemic and earned him a letter of appreciation from the King of Prussia, Friedrich Wilhelm III. ${ }^{6}$

\footnotetext{
${ }^{5}$ For details of these actions, see Blum (1938): 82-83. For the Hebrew translation of the original instruction manual published in German written in Hebrew letters, see Auerbach (1966): 9-12.

6 For the text of Friedrich Wilhelm III's letter published in the press, see Blum, 1938. Rabbi Eger's perspective regarding his actions to prevent the spread of cholera and his instructions to the Jewish public at
} 


\section{Rabbis' Instructions and Halachic Decisions in Light of the Corona Virus Epidemic}

Following Rabbi Eger's lead, rabbis around the world are striving to guide their communities during the Corona epidemic. Many rabbis have noted that apart from the obligation to God and to the other, there is a duty to obey the state. The underlying rationale is found in the Talmud. Dina de-malkhuta dina meaning "the law of the land is the law" is a principle in Jewish religious law, which holds that the civil law of the country is binding upon the Jewish inhabitants of that country and, in certain cases, overrides Jewish law. The concept of dina de-malkhuta dina, which is similar to that of a conflict of laws in other legal systems, means that for Jews, obedience to the civil law of the country in which they live is viewed as a religiously mandated obligation and that according to Jewish law, disobedience is a transgression. ${ }^{7}$ Adherence to this principle can be seen among rabbis all over the world ${ }^{8}$ : The Chief Rabbis of Israel maintain that one is obligated to abide by all the directives of the Ministry of Health designed to prevent the spread of the Corona virus, even if it involve the suspension of certain religious laws, such as prayers in a minyan, noting: "It is an obligation to obey the directives of the Ministry of Health, as every health instruction is a religious law (halacha) at this time."

Israel's Sephardic Chief Rabbi Yitzhak Yosef ruled that, owing to the coronavirus pandemic, religiously observant people must keep their cellphones open on Shabbat because authorities might have to contact them with lifesaving information. He also called for the closure of all hospital synagogues, noting that these, often small, prayer spaces do not allow worshippers to abide by the Health Ministry's demand for of least a $2 \mathrm{~m}$ (6.6-feet) space between one person and another. The rulings, which the rabbi's office referred to as "dramatic," are based on the Jewish legal principle that saving a life-or pikuah nefesh, as it is known in Hebrew-trumps nearly all other religious requirements. The use of electronic equipment is normally not permitted on the Jewish day of rest by religious law (Times of Israel 2020).

At the same time, Jewish communities around the world have closed their synagogues despite the fact that praying with a minyan has been an important element in Jewish community life for some 2000 years. Nevertheless, the move is thought to be necessary in the face of the challenges posed by Corona, which are now high on

\footnotetext{
Footnote 6 (continued)

that time, including detailed descriptions of the epidemic and actions for public hygiene can be found in Letters of Rabbi Akiva Eger, letters 146-148.

7 For further discussion, see Galas (1979), Lorberbaum (2000).

${ }^{8}$ It is worth noting that not all religious communities around the world have followed these guidelines. Many members of various Jewish groups have not abided by the instructions of health authorities, mainly those from Ultra-Orthodox communities, which are also opposed to having their children vaccinated. Some perceive these requirements as, so to speak, loss of faith in G-d, and they rely on biblical verses such as "The Lord protects the unwary" (Psalms 116:6) or "Whoever obeys His command will come to no harm" (Ecclesiastes 8:5). Some do not recognize the legitimacy of secular institutions to interfere with religious observances. In some cases, police enforcement has been necessary and in others, only pressure from the general public has forced compliance with the instructions of the health authorities.
} 
the agenda of Jewish communities around the world. ${ }^{9}$ Apart from canceling communal prayer, chief rabbis and community leaders have also called upon people to self-isolate voluntarily at home. Some rabbis see these moves as direct applications of the relevant biblical commandments, which provides religious validation for the medical directives.

In an unprecedented step, on March 3, 2020, Rabbi Ephraim Mirvis, the Chief Rabbi of the United Kingdom, announced that, in view of the seriousness of the Corona virus pandemic, the United Synagogue, the largest network of Orthodox communities in the country, would be shutting down all activities until further notice. Daily and Shabbat prayer services as well as all other events and activities ceased at the more than sixty synagogues of the association, which comprises 40,000 members. In a public statement, Mirvis declared:

It is now clear from the government's latest guidance that congregational activity of any kind, including those of religious communities, poses a significant danger to the vulnerable and will serve to hasten the spread of the virus. With this in mind, our Torah obligation to protect the sanctity of life transcends all other considerations. Therefore, with much pain and with the heaviest of hearts, in consultation with the Dayanim [rabbinic judges] of the London and Manchester Batei Din, I have concluded that we have a halachic imperative to suspend all activity at all of our synagogues until further notice.

Mirvis added that this means that all on-site and off-site prayer services, educational, cultural and social meetings, and activities for all ages would be suspended and noted that he and the rabbinical judges associated with the United Synagogue would be praying at home:

Let us guarantee that the physical distance that this virus creates between us will be bridged through compassion and kindness (Sharon 2020).

In the USA, officials in the White House held a conference call on March 17, 2020, with fifteen of the leading rabbis from New York's Orthodox Jewish community to urge them to follow the administration's guidelines to limit the number of attendees at social gatherings to ten people. Avi Berkowitz, an assistant to US President Donald Trump, spoke with the rabbis for 45 min, going over the Trump administration's new guidelines. Berkowitz was asked if the learning of Torah could take place in the same building but in different rooms in groups of no larger than ten people. He responded that it would be problematic, telling the rabbis that this is a situation of pikuah nefesh. He told the rabbis that it is crucial to follow the guidelines even though they are not mandatory because someone could carry the virus and infect vulnerable people (Nahmias 2020).In Morocco, synagogues also closed over coronavirus fears. The Council of Jewish Communities in Morocco (CCIM) issued a press release stating that following official directives and consultation within the

\footnotetext{
9 On the synagogue's contribution as a platform for influencing the community agenda, see Hellinger and Rashi (2009), Rashi and McCombs (2017).
} 
rabbinate, it is recommending the suspension of prayers in synagogues until further notice, adding:

We urge places of worship leaders to show solidarity and responsibility and follow preventive measures. In any case, it is strictly mandatory to comply with recommendations issued by the health authorities and not have more than a maximum 10 faithful per office. We remain at your disposal and will keep you informed of any developments regarding the current situation. (Babas 2020)

The Rabbinical Council of Australia and New Zealand (RCANZ) also decreed the closing all synagogues in those countries, calling it "a religious obligation" (Australian Jewish News 2020).

\section{The Correct Religious Attitude to Quarantine Violators Based on Religious, Moral, and Civic Obligations}

Rabbi Asher Weiss (Israel, 1953-), a rabbi of the Sanz Chassidic sect and the chaplain of Shaare Zedek Hospital in Jerusalem, who is one of the most important contemporary rabbis in the city, has ruled that every person is obliged to be careful about danger and not to endanger himself and others in medical terms, even though statistics might indicate relatively low risks regarding the potential harm to others. $\mathrm{He}$ insisted that one must follow the directives of the competent medical authorities and the regulations of the Ministry of Health, without deviation, and that those who are ordered into quarantine should not leave their homes so as not endanger the public. In this ruling, he is basically adhering to all the duties noted herein: man's religious duty to his God, man's moral responsibility toward others, and the obligation of a citizen to the state in which he lives.

Rabbi Weiss's reasoning reminds us of Kant's categorical imperative, although he formulates his position as a religious obligation. Kant, as is well known, ruled regarding the categorical imperative: "Act only according to that maxim whereby you can, at the same time, will that it should become a universal law" (Kant 1993:30). According to Rabbi Weiss, any act if carried out by many will lead to harm and injustice, and even if no harm or injustice happens to the individual performing the act, he is nonetheless forbidden to engage in it. In other words, the individual is prohibited from doing what is forbidden for the many. Rabbi Weiss calls someone who engages in such a forbidden act "a scoundrel within the bounds of the Torah," basing this principle on the Babylonian Talmud, the Jerusalem Talmud, and the Midrashim of the Sages. ${ }^{10}$

In Treatise Sanhedrin 109B, the Talmud describes the behavior in Sodom on the occasion when someone came to the town market to sell garlic and onions, and every passerby took just one item, saying: "I took just one," thereby impoverishing the seller.

\footnotetext{
10 A similar worldview can be seen in Rabbi Weiss' ruling on the principle and the religious obligation to vaccinate children against various diseases. In this regard, see: Rashi (2020).
} 
Rashi explained that each one said, "I only took something small," but the end result was that together they stole everything the seller had. The Jerusalem Talmud, Treatise Baba Metsia 16A, ascribes this behavior to people of the generation of the Flood, thus understanding the biblical description "for the earth is filled with robbery":

What is robbery and what is theft? Rabbi Chanina said: robbery-not even minimum value, theft-minimal value. This is what people before the Flood did: One of them took his bag of beans to the market and someone came and took less than the minimal value, and another took less than the minimal value, so that he could not sue him. G-d said: You did not act properly-I too will not act properly with you. (Bereishit Rabba 31)

From these sources, Rabbi Weiss infers the principle that if something done by many involves evil and sin, then it is forbidden for an individual to do it. The same applies in the present case concerning individuals who violate quarantine. The few people who violate the quarantine will not cause the death of all humanity, but if anyone does, eventually everyone will violate the quarantine and many people will die. Thus, it is also forbidden for the individual to violate a quarantine, and one must denounce people who do so (Weiss 2020).

\section{Conclusion}

The requirement to preserve the health of both the individual and the community is not just a medical issue. Throughout history, beginning from the time of the Bible, the understanding has been formulated within Judaism that part of an individual's religious obligations is to look after his/her health and the health of the community, both in normal times and in emergencies. If normal times require looking after one's health, certainly during epidemics rabbis were in no doubt and are still in no doubt about the need to suspend customs and even adherence to fundamental Jewish laws in order to protect the health of the public.

The religious justification for protecting public health and anchoring public conduct in religious directives is likely to reduce the risk of harm to public health. It would be useful for future research to try to uncover justifications in other religions for the protection of public health even those at the cost of suspending religious mandates.

\section{Compliance with Ethical Standards}

Conflict of interest The authors declare that they have no known competing financial interests or personal relationships that could have appeared to influence the work reported in this paper.

\section{Bibliography}

Auerbach, M. (1966). Instructions for the holy days of 1832 in the Posen community. Ha-Mayan, 6(1), 9-12. (In Hebrew). 
Australian Jewish News. (2020). All synagogues told to stop minyanim. Retrieved March 17, 2020 from https://ajn.timesofisrael.com/all-synagogues-told-to-stop-minyanim/

Babas, L. (2020). Coronavirus: The council of Jewish communities in morocco wants to stop prayers in synagogues. Retrieved March 17, 2020 from https://en.yabiladi.com/articles/details/90704/coron avirus-council-jewish-communities-morocco.html

Blum, S. (1938). Rabbi Akiva Eger's life: His life and his actions. Warsaw: Blum.

Eger, R. A. (1969). Commentaries on the Tractate Nedarim. Jerusalem: Igud Bnei Hayeshivot.

Eger, R. A. (1994). Letters of Rabbi Akiva Eger. Jerusalem: Da'at Sofer Institute.

Falagi, H. (1832). Nishmat Kol Hai. Thessaloniki: Ashkenazi. [In Hebrew].

Galas, Y. (1979). Halacha and the law of the land. Halacha: A guide to its understanding in theory and practice, based on the meforshim (Expositors) and Posekim (Decisors) of the past and present. New York: Judaica Press.

Hellinger, M., \& Rashi, T. (2009). The Jewish custom of delaying communal prayer: A view from communication theory. Review of Rabbinic Judaism, 12(2), 189-203.

Jerusalem Post. (2020). Chief Rabbi: Afraid of coronavirus? don't kiss the mezuzah. Retrieved March 4, 2020 from https://www.jpost.com/Israel-News/Chief-Rabbi-of-Israel-Due-to-Coronavirus-stop-kissi ng-the-mezuzah-619753

Kant, I. (1993). [1785]. Grounding for the metaphysics of morals. Translated by James W. Ellington (3rd ed.). Indianapolis: Hackett.

Lipschitz, I. (2015). Commentary on the Mishnah. Jerusalem: Otzar Hasefer. (In Hebrew).

Lorberbaum, M. (Ed.). (2000). The Jewish political tradition: Volume 1-authority (pp. 431-434). New Haven: Yale University Press.

Maimonides, M. (1954). The code of maimonides (Mishneh Torah) (trans. Herbert Danby). New Haven: Yale University Press.

Nahmias, O. (2020). Donald Trump assistant urged NY rabbis to follow guidelines. Retrieved March 18, 2020 from https://www.jpost.com/Diaspora/Donald-Trump-assistant-urged-NY-Rabbis-to-follo w-guidelines-621376

Rashi, T. (2020). Jewish ethics regarding vaccination. Public Health Ethics. https://doi.org/10.1093/phe/ phaa022.

Rashi, T., \& McCombs, M. (2017). Biblical antecedents of modern agenda-setting: Religious platforms in lieu of mass media. Essachess-Journal for Communication Studies, 10(2), 77-92.

Samuel, J. B. (2002). Book of Chasidim. Jerusalem: Rav Kook Institute. (In Hebrew).

Sharon, J. (2020). UK United Synagogue network shuts down completely due to coronavirus. Retrieved March 17, 2020 from https://www.jpost.com/Diaspora/UK-United-Synagogue-network-shuts-downcompletely-due-to-coronavirus-621360

Shlomo, D. (1968). Responsa of Rabbi Shlomo Ben Shimon. Jerusalem: Brodner.

Shulchan, A. (2009). Tel Aviv: Miscal. (In Hebrew).

The Mishnah: A New Translation. (Trans. Jacob Neusner). (1991). New Haven: Yale University Press.

The Schottenstein Edition Talmud Bavli. (1990-2012). New York: Artscroll.

Times of Israel. (2020). Chief rabbi allows cellphones on Shabbat for lifesaving virus messages. Retrieved March 19, 2020 from timesofisrael.com/chief-rabbi-allows-cellphones-on-shabbat-for-lifesaving -virus-message/

Weiss, A. (2020). The Corona in Halacha. https://www.torahbase.org/\%d7\%94\%d7\%a7\%d7\%95\%d7\%a $8 \% \mathrm{~d} 7 \% 95 \% \mathrm{~d} 7 \% \mathrm{a} \% \mathrm{~d} 7 \% 94-\% \mathrm{~d} 7 \% 91 \% \mathrm{~d} 7 \% 94 \% \mathrm{~d} 7 \% 9 \mathrm{c} \% \mathrm{~d} 7 \% 9 \mathrm{~b} \% \mathrm{~d} 7 \% 94-\% \mathrm{~d} 7 \% \mathrm{aa} \% \mathrm{~d} 7 \% \mathrm{a} 9 \% \mathrm{~d} 7 \% \mathrm{a} 4 /$ (In Hebrew)

Publisher's Note Springer Nature remains neutral with regard to jurisdictional claims in published maps and institutional affiliations. 